\title{
PERANCANGAN MODEL TRANSPORMASI PENDIDIKAN TEKNOHUMANISTIK YANG TERINTEGRASI DENGAN PEMBELAJARAN TEMATIK DI SEKOLAH DASAR
}

\author{
I Nyoman Natajaya ${ }^{1}$, Nyoman Dantes ${ }^{2}$ \\ 1,2 Program Pascasarjana, Universitas Pendidikan Ganesha \\ Singaraja, Indonesia
}

Email: natajaya@yahoo.com

\begin{abstract}
Abstrak
Penelitian ini menggunakan rancangan penelitian pengembangan dengan tujuan untuk mencari dan menggali imformasi (1) nilai karakter yang berbasis teknohumanistik yang dapat diintegrasikan dengan pembelajaran tematik di SD, (2) model-model pembelajaran inovatif yang dapat digunakan untuk mentransformasikan nilai-nilai karakter yang berbasis pada pendidikan teknohumanistik, dan (3) implementasi pengembangan model transformasi pendidikan teknohumanistik yang terintegrasi dengan pembelajaran tematik di SD. Sampel penelitian ini ádalah 100 orang guru SD dengan perincian di Bali barat, selatan, timur dan Bali utara masing-masing 25 orang. Pengumpulan data dilakukan dengan teknik wawancara, kuesioner tertutup dan kuesioner yang terbuka. Analisis data dilakukan secara desktiptif kualitatif. Temuan penelitian sebagai berikut. Pertama menunjukkan bahwa kualitas transformasi pendidikan teknohumanistik guru-guru SD di Bali cendrung dapat dikategorikan sangat baik. Kedua semua guru guru (100\%) menyatakan telah melakukan pembelajaran tematik, di samping itu guru-guru juga menyatakan menerapkan model pembelajaran yang lainnya, seperti model pembelajaran CTL $33 \%$, ceramah $19 \%$, kerja kelompok dan penugasan masing-masing $17 \%$, jigsaw dan tanya jawab masing-masing $16 \%$, diskusi $15 \%$, STAD $11 \%$, demonstrasi dan pemecahan masalah masing-masing $8 \%$, inquiri $6 \%$, CBSA dan quantum masing-masing $3 \%$, SAS dan eja masing-masing $2 \%$, dan pakem $1 \%$. Ketiga ditemukan bahwa di dalam setiap langkah pelaksanaan pembelajaran tematik dalam langkah pertama, kedua dan ketiga tampak terjadi perbedaan kegiatan dan bahkan suatu kegiatan tertentu tidak dilakukan, Namun, secara teoretis langkah-langkah yang sudah dilakukan tersebut dapat dikatakan sudah baik, demikian juga masih ada kelemahannya karena berbagai kegiatan yang seharusnya dilakukan dalam setiap langkah cendrung tidak dilakukan.
\end{abstract}

Kata Kunci: Pendidikan teknohumanistik, Pembelajaran tematik. 


\begin{abstract}
This study used development research design aimed at seeking information on (1) character values that are based on techno-humanistic model that can be integrated into primary school thematic education, (2) innovative learning models that can be used to transform character values that are based on techno-humanistic model, (3) implementation of techno-humanistic education transformation model that is integrated into primary school thematic education The study used a sample of 100 primary school teachers: 25 from each of West Bali, South Bali, East Bali and North Bali. The data were collected by interview, closed questionnaire, and open questionnaire and were analyzed by a qualitative-descriptive analy-sis. The findings are: first, the quality of teachers' techno-humanistic education transformation at the primary schools in Bali tends to fall into very good category. Second, all teachers $(100 \%)$ stated that they had done thematic education. In addition they also said that they had implemented other models, such as CTL (33\%), lecturing $(19 \%)$, group work and assignment, each of which was $17 \%$, jigsaw, question and answer (16\% each), discussion (15\%), STAD (11\%), demonstration and problem solving ( $8 \%$ each), inquiry ( $6 \%)$, SAL and quantum learning (3\% each), SAS and Spell $(2 \%$ each) and Pakem (1\%). The third finding was that in each step of the first, second, and third, in implementing the thematic education there occurred activity differences and even a particular activity was not done. However, in theory, the steps that were taken can be said to have been good and appropriate. On the other hand, there was a weakness since a step that ought to be taken tended to be missed.
\end{abstract}

Keywords: techno-humanistic education, thematic education.

\section{PENDAHULUAN}

Pendidikan merupakan proses pemanusiaan manusia, dalam arti bahwa pendidikan adalah merupakan sebagai upaya optimalisasi perkembangan harkat dan martabat manusia (Dantes, 2010). Demikian pula berarti pendidikan pada hakikatnya harus berlangsung di lingkungan masyarakat manusia. Pada saat ini perkembangan masyarakat manusia makin maju dengan ditemukannya iptek oleh manusia untuk menjawab permasalahan kehidupan yang dihadapinya, dan untuk pengembangan ilmu itu sendiri. Dalam konteks itu, ilmu memiliki tiga dimensi yaitu dimensi ontologi, epistimologi dan aksiologi. Ontologi berbicara mengenai objek ilmu, yang dalam perkembangannya didasarkan pada prosedur ilmiah, yaitu verifikasi terbuka, objektif dan jujur dalam satu bingkai epistimologi, yang diharapkan dapat memberikan maslahat pada kehidupan manusia sebagai dimensi aksiologi. Itulah yang menjadi dasar pengembangan ilmu yang berbasis pada nilai kemanusiaan (Suriasumantri, 1984)

Makin maju suatu masyarakat, kebutuhan dan tuntutan kehidupannya semakin terdiferensiasi dan terspesifikasi, sehingga memunculkan kehidupan yang cenderung individual yang berbasis pada kebutuhan material, yang secara pelan akan menyebabkan munculnya kehidupan masyarakat yang menonjolkan egoisme kelompok atau pribadi, mengabaikan dan mengarah pada memudarnya nilai-nilai harkat kemanusiaan pada generasi muda dalam pendidikan formal, informal dan

Jurnal Pendidikan Indonesia/ 600 
nonformal. Hampir semua aktivitas pendidikan di sekolah dilakukan dalam rangka pengembangan iptek semata, yang didominasi dengan aktivitas pikir saja. Hal ini berlangsung begitu cepat dan seragam, sehingga dengan cepat pula terasa keringnya kehidupan tanpa didasari pada nilai-nilai kebersamaan, menghadirkan tantangan dan peluang baru bagi umat manusia dalam semua sisi kehidupan. Kondisi ini semakin diperkuat oleh semakin menggejalanya kehidupan global, sehingga setiap manusia dan bangsa harus siap untuk melakoni kehidupan yang tanpa batas, yang menuntut untuk selalu siap berkompetisi agar eksis dalam konstelasi kehidupan yang serba dinamis. Revolusi informasi dan komunikasi sebagai dampak dari kemajuan iptek telah menghilangkan batas-batas wilayah, sehingga bagi masyarakat tertentu, kondisi ini harus disikapi dengan cepat dan komprehensif agar mereka tidak kehilangan jati diri.

Dalam kehidupan di era global ini, ada bukti menunjukan semakin merosotnya pemahaman, pemilikan dan penerapan nilai-nilai kemanusiaan dalam masyarakat, sehingga mengakibatkan terjadinya berbagai perilaku yang tidak normatif, seperti perilaku kekerasan, pelanggaran HAM, dan pembunuhan yang melanggar harkat kemanusiaan.

Bagi dunia pendidikan, dengan adanya kecenderungan pendidikan yang dilakukan semata-mata untuk penguasaan iptek merupakan suatu realitas yang harus disikapi, pendidikan tidak boleh hanya didasarkan pada penguasaan iptek saja, tetapi harus dikombinasi diorkestra secara terpadu dengan nilai-nilai kemanusiaan.
Sehingga pendidikan menjadi bermakna dalam arti dapat memberikan bagi setiap peserta didik memperoleh iptek, keterampilan, dan nilai-nilai kemanusiaan sebagai bekal mereka memasuki persaingan di dunia global. Dalam era globalisasi dan reformasi ini telah terjadi pula pergeseran paradigma dalam pendidikan, yaitu: pertama, proses pendidikan yang pada mulanya berorientasi pada guru lebih menjadi pusat informasi, bergeser pada proses pendidikan yang berorientasi pada pembelajaran yang menjadikan peserta didik sebagai pusat pembelajaran. Kedua, proses pendidikan tradisional yang berorientasi pada pendekatan klasikal dan diformat di dalam kelas, bergeser ke model pembelajaran yang lebih fleksibel, seperti pendidikan sistem jarak jauh. Ketiga, mutu menjadi prioritas. Keempat, semakin populernya sistem pendidikan seumur hidup dan semakin mencairnya batas antara pendidikan di sekolah dan di luar sekolah. Kelima, pendidikan Iptek semakin berkembang, yang didasari pada nilai-nilai kemanusiaan, dan menuntut suatu model pendidikan yang mampu mentransformasikan bekal keintelekan dengan dasar keadaban yang kokoh, yang disebut dengan suatu model pendidikan teknohumanistik.

Pendidikan teknohumanistik pada dasarnya merupakan suatu upaya dalam mentransformasikan iptek dan nilai-nilai keadaban yang didasarkan pada beberapa prinsip: (1) Pendidikan teknohumanistik agar mengembangkan "Core Ethical Values" sebagai basis dari inti karakter kemanusiaan yang baik, seperti: kepedulian, kejujuran, keterbukaan, tanggung jawab, dan rasa hormat pada diri sendiri dan orang lain, 
sebagai basis daripada karakter yang baik, yang mendasari penguasaan iptek, (2) Pendidikan teknohumanistik, seyogianya didefinisikan secara komprehensif, yang mencakup pikiran, perasaan, dan perilaku. (3) Dalam pendidikan formal, pendidikan teknohumanistik menuntut niat yang sungguh-sungguh, proaktif, komprehensif dan pendekatan yang dapat memacu nilai-nilai inti pada semua tahap kehidupan sekolah. Sekolah dalam melakukan pendidikan teknohumanistik, seyogyanya disorot melalui lensa moral dengan melihat segala sesuatu yang berpengaruh terhadap nilai-nilai karakter peserta didik, dan (4) Sekolah harus menjadi "a caring community". Sekolah harus menampakkan diri sebagai lembaga yang memiliki karakter yang baik.

Ada tiga tujuan dari pendidikan teknohumanistik, yaitu penguasaan iptek, kebijakan dan kebaikan. Penguasaan iptek harus berdasar pada aksiologi keilmuan yaitu demi kemaslahatan dan kesejahtraan umat manusia. Pendidikan persekolahan yang terkait dengan aplikasi pada berbagai lapangan yang merupakan usaha strategis untuk pencapaian tujuan pendidikan dalam rangka pembentukan karakter peserta didik. Oleh karena itu maka ada dua nilai moral utama yang perlu dibelajarkan di sekolah, yaitu "respect and responsibility". Di samping nilai-nilai utama nilai-nilai lainnya yang perlu dibelajarkan di sekolah, adalah: kejujuran, keterbukaan, toleransi, kehatihatian, disiplin diri, membantu dengan tulus, rasa haru, bekerjasama, keteguhan hati, dan nilai-nilai demokrasi” (Lickona, 1991: 43-45).
Karakter mencakup dan berkaitan dengan pengetahuan moral, perasaan moral, dan perilaku moral. Pengetahuan moral, memiliki beberapa aspek, yaitu: (1) kesadaran moral, (2) pengetahuan nilai moral, kemampuan untuk memberi pandangan kepada orang lain, melihat situasi seperti apa adanya, bagaimana dia berpikir, bereaksi, dan merasakan, (4) pemahaman tentang apa yang dimaksud dengan bermoral dan mengapa harus bermoral, (5) kemampuan mengambil keputusan dalam menghadapi masalah-masalah moral, (6) kemampuan mengenal atau memahami diri sendiri.

Dalam komponen perasaan moral terdapat enam aspek penting, yaitu (1) kata hati atau hati nurani, yang memiliki dua sisi, yakni sisi kognitif dan sisi emosi, (2) harga diri, (3) kemampuan untuk mengidentifikasi diri dengan orang lain, (4) tertarik dengan kebaikan yang sejati, (5) kemampuan mengendalikan diri sendiri, yang berfungsi untuk mengekang kesenangan diri sendiri, dan (6) kerendahan hati.

Dalam komponen tindakan moral terdapat tiga aspek penting, yaitu: (1) kompetensi moral, yakni kemampuan untuk menggunakan pertimbangan moral dalam berperilaku moral yang efektif; (2) kemauan, yakni pilihan yang benar dalam situasi moral tertentu, dan (3) kebiasaan, yakni suatu kebiasaan untuk bertindak secara baik dan benar. Dantes (2009) telah melakukan dan mengembangkan suatu perspektif tentang integrasi nilai-nilai karakter dengan pengembangan Iptek yang diterapkan dalam dunia pendidikan, yang disebutnya dengan pendidikan 
karakter dalam perspektif teknohumanistik. Demikian pula lebih lanjut Dantes (2010) dalam penelitian pendidikan karakter yang berbasis teknohumanistik di sekolah menemukan bahwa aspek-aspek karakter yang harus dikembangkan bersamaan dengan iptek meliputi: kesadaran moral, pengetahuan nilai-nilai moral, kemampuan memberi pandangan dan pertimbangan moral, memahami diri sendiri, pandangan terhadap pekerjaan, kata hati, harga diri, empati, cinta kebaikan, pengendalian diri, rendah hati, rasa terharu, kejujuran, loyalitas, keyakinan, kompetensi moral, kemauan, tanggungjawab, kebiasaan, disiplin, persahabatan, keberanian dan keteguhan hati, pengambilan keputusan, dan ketekunan.

Semua aspek karakter yang sesuai dengan adab kemanusiaan tersebut sangat diperlukan dalam pengembangan iptek, karena kehidupan ke depan sangat berat dan kompetitif, oleh karenanya ke depan diperlukan suatu sistem pendidikan yang menguasai iptek yang tinggi, serta harus didasarkan pada pemahaman dan penguasaan nilai-nilai karakter yang mulia agar dapat menjawab tantangan kehidupan yang berat dan kompetitif. Dalam hubungan ini Scalia (dalam Elmubarok. 2009) menguraikan bahwa karakter harus menjadi pondasi bagi kecerdasan dan pengetahuan. Informasi memang bisa diperjual belikan, dan sudah menjadi pengetahuan umum bahwa di era knowledge economy abad 21 ini knowledge adalah power. Masalahnya adalah bila orang-orang yang dikenal cerdas dan berpengetahuan tidak menunjukkan dan memiliki karakter, maka tidak diragukan lagi bahwa dunia akan menjadi lebih dan menuju kearah semakin buruk. Tampaknya memang benar adanya ungkapan yang menyatakan knowledge is power, but character is more. Demikian juga Marvin Brekowitz (dalam Rohman. 2012) menyatakan betapa pentingnya peran pendidikan karakter dalam rangka untuk peningkatan motivasi siswa dalam meraih prestasi akademik yang terbukti pada sekolahsekolah yang telah menerapkan pendidikan karakter sejak pendidikan dasar, seperti di Amerika Serikat, Jepang, Cina dan Korea. Sejalan dengan pendapat Marvin Brekowitz adalah pendapat yang dikemukakan oleh Daniel Goleman yang menyatakan bahwa keberhasilan anak atau seseorang di masyarakat ternyata $80 \%$ dipengaruhi oleh kecerdasan emosi, dan hanya $20 \%$ dipengaruhi oleh kecerdasan otak. Anak-anak yang memiliki masalah dalam kecerdasan emosi akan mengalami masalah dalam belajar, bergaul dan akan tidak dapat mengontrol emosinya.

Banyak kajian yang dapat ditunjuk sebagai referensi tentang perubahan zaman yang telah dilakukan oleh para ahli yang meyakinkan bahwa dalam upaya menghadapi perubahan dan tantangan jaman ini memberikan gambaran bahwa begitu pentingnya pendidikan karakter yang berbasis teknohumanistik, seperti, Naisbitt dan Aburdene (1990), Naisbitt (1995), McRae (1995). Kajian-kajian tersebut juga didukung oleh hasil penelitian Joseph Jin (dalam Rohman. 2012) yang mengkompilasikan berbagai hasil penelitian yang menemukan bahwa terdapat pengaruh positif kecerdasan emosi anak terhadap keberhasilan di 
sekolah. Ditemukan juga bahwa ada beberapa faktor resiko sebagai penyebab kegagalan anak di sekolah. Faktor-faktor resiko yang dimaksudkan ternyata bukan terletak pada kecerdasan otak, tetapi justru pada faktor karakter, yaitu percaya diri, kemampuan bekerja sama, kemampuan bergaul, kemampuan berkonsentrasi, rasa empati, dan kemampuan berkomunikasi. Selanjutnya berdasarkan perspektif pendidikan karakter berbasis teknohumanistik dan hasil need assessment di atas, tampaknya perlu dikembangkan prototipe awal mengenai pendidikan karakter berbasis teknohumanistik pada pendidikan formal di Indonesia yang terdiri atas tiga dimensi yang tercakup dalam pendidikan karakter berbasis teknohumanistik, yaitu: (1) penguasaan iptek, (2) penguasaan nilai-nilai moral, serta (3) penerapan nilai-nilai kebijaksanaan. Dimensi penguasaan Iptek, penguasaan nilai-nilai moral dapat dilakukan dan ditransformasikan melalui pilar pembelajaran learning to know, learning to do, dan learning to be; sedangkan nilai-nilai kebijaksanaan dapat ditransformasikan melalui learning to live togather dan learning to live sustainability. Transformasi dimensi satu dan dua adalah tahap pembentukan dan pengembangan nilai karakter itu sampai dikuasai oleh peserta didik, sedangkan dimensi tiga merupakan implementasi nilai tersebut dalam kehidupan.

Berbagai aspek dari pendidikan teknohumanistik telah dijelaskan di atas, pengertiannya, prinsip-prinsipnya, dan pendekatannya. Dengan demikian sudah tergambar apa yang dimaksud dengan model pendidikan tehnohumanistik walaupun tidak secara lengkap. Di sisi lain secara teori juga dijelaskan bahwa untuk dapat berhasilnya transformasi pendidikan teknohumanistik tersebut di sekolah, maka dalam transformasi pendidikan teknohumanistik diharapkan menggunakan pembelajaran tematik. Permasalahanya muncul bagaimanakah transformasi pendidikan tehnohumanistik dapat diintegrasikan dengan model pembelajaran tematik. Oleh karena itu tampaknya perlu dijelaskan pembelajaran tematik tersebut.

Pembelajaran tematik adalah pembelajaran terpadu yang menggunakan tema sebagai pokok atau kajian yang memungkinkan dapat mengaitkan atau mengintegrasikan pencapaian tujuan-tujuan belajar beberapa mata pelajaran terkait sehingga memberikan pengalaman belajar secara langsung dan fowerful kepada anak didik. Demikian pula tema yang dimaksudkan disini adalah pokok pikiran atau gagasan pokok yang dijadikan pokok pembahasan dalam pembelajaran yang berkaitan dengan pengalaman anak didik.

Pembelajaran tematik memiliki arti yang sangat penting bagi pendidikan anak usia dini di sekolah dasar, diantaranya: (1) memberikan pengalaman belajar yang nyata dan langsung kepada anak dalam rangka membangun sistem pengetahuan yang bermakna, (2) memungkinkan anak dapat belajar sesuai dengan tingkat dan irama pertumbuhan dan perkembangan anak, (3) lebih sesuai dengan karakter anak belajar anak, antara lain: belajar secara utuh, belajar sambil bermain, belajar yang menyenangkan, belajar sambil melakukan dan bekerja sama 
sebagai masyarakat pebelajar, belajar mengalami secara nyata dan langsung, dan belajar lebih fowerful, (4) membantu siswa berfokus pada persoalan nyata yang dihadapi anak didik dan masyarakat sehingga memungkinkan siswa belajar bermakna dan turut berkontribusi bagi perbaikan masyarakat, dan (5) dapat menghindarkan anak dari tindakan kekerasan dan penjajahan dalam pendidikan dan pembelajaran.

Pelaksanaan

model

pembelajaran tematik yang berfokus pada tema dalam pelaksanaannya seharusnya mengikuti tahapan-tahapan pembelajaran, yaitu pertama pembukaan atau kegiatan pendahuluan yang bertujuan untuk memfokuskan perhatian siswa, kedua kegiatan inti dilakukan untuk memberikan bimbingan belajar, serta pengalaman belajar kepada anak untuk mencapai tujuan pembelajaran yang telah ditetapkan, dan kegiatan ketiga adalah kegiatan penutup yang umumnya bertujuan untuk memformulasikan hasil belajar, menilai keberhasilan pencapaian tujuan pembelajaran, dan merencanakan kegiatan tindak lanjut. Apabila pembelajaran pendidikan teknohumanistik dintegrasikan dengan pembelajaran tematik, ini berarti mentransformasikan nilai-nilai karakter tersebut dengan langkah atau tahapan pembelajaran tematik tersebut. Jadi semua nilai-nilai karakter tersebut melifuti karakter yang berkaitan dengan pengetahuan moral, perasaan moral, dan perilaku moral.

Dari nilai-nilai karakter yang mencakup pengetahuan moral, perasaan moral, dan perilaku moral tersebut dalam penelitian ini dikembangkan menjadi 20 nilai karakter yang diteliti dan meliputi: kesadaran moral, pengetahuan nilai moral, kemampuan memberi pandangan dan pertimbangan moral, mengenal dan memahami diri, pandangan terhadap pekerjaan, kata hati/hati nurani, harga diri, empati, cinta pada kebaikan, pengendalian diri, rendah hati, rasa terharu, kejujuran, loyalitas, keyakinan, kompetensi moral, kemauan, kebiasan, tanggungjawab,

persahabatan keberanian dan keteguhan hati, ketekunan, dan pengambilan keputusan.

Berdasarkan pada uraian tentang pendidikan teknohumanistik dan model pembelajaran tematik dan berbagai permasalahannya, maka penelitian ini dilakukan dengan tujuan untuk menjawab permasalahan: (1) Nilai karakter yang bagaimanakah dapat diintegrasikan dalam pembelajaran tematik khususnya di SD, (2) Modelmodel pembelajaran inovatif yang bagaimanakah cocok digunakan untuk mentranspormasikan nilai-nilai karakter yang berbasis pada pendidikan teknohumanistik, (3) Bagaimana model transformasi pendidikan teknohumanistik yang terintegrasi dengan pembelajaran tematik di Sekolah Dasar dapat dikembangkan.

Dengan dilakukannya penelitian ini, dan mengambil objek tentang model transformasi

pendidikan teknohumanistik yang terintegrasi dengan pembelajaran tematik di Sekolah Dasar maka hasil penelitian ini memiliki urgensi yang sangat tinggi bagi semua komponen yang terlibat dalam dunia pendidikan khususnya di sekolah dasar. Secara teoretis urgensinya adalah diharapkan akan dapat menambah wawasan keilmuan dan 
memperkaya teore-teore pendidikan. Demikian juga urggensi praktisnya terutama bagi guru sekolah dasar di lapangan dapat dijadikan sebagai suatu alternatif model pembelajaran yang mengitegrasikan antara transformasi iptek dengan nilai-nilai yang berbasis nilai-nilai untuk pembentukan karakter.

\section{METODE}

Penelitian ini menggunakan pendekatan pengembangan. Borg dan Gall (1989: 626) menjelaskan ada 10 langkah kegiatan dalam penelitian pengembangan. Dari 10 langkah kegiatan tersebut diperas lagi menjadi tujuh langkah pokok yaitu, (1) research and information collecting. Pada langkah ini peneliti melakukan analisis kebutuhan, studi literatur dan survey terbatas. Analisis kebutuhan dilakukan untuk mengetahui produk yang akan dihasilkan, kelayakan produk, tenaga pelaksana dan waktu yang tersedia. (2) planning. Pada kegiatan ini peneliti merumuskan rencana penggunaan hasil penelitian, sasaran atau pengguna hasil penelitian, dan deskripsi komponenkomponen hasil penelitian serta, (3) develop preliminary form of product yaitu menyusunan draf uji coba hasil penelitian di lapangan, (4) preliminary field testing and product revision yaitu melakukan evaluasi hasil penelitian untuk mengetahui apakah hasil penelitian dapat dikembangkan atau tidak, (5) main field test and product revision yaitu melakukan uji kembali hasil-hasil yang telah dicapai, (6) operational field test and product revision yaitu mengkaji apakah hasil penelitian benar-benar dapat digunakan oleh praktisi pendidikan sebagai pelaksana dan pengembang pendidikan, dan (7) dessemination implementastion and institutionalization, yaitu melakukan desiminasi hasil-hasil penelitian melalui lembaga atau sekolah.

Penelitian ini dilakukan terbatas pada tahap pertama hanya melakukan analisis kebutuhan, studi literatur dan survey terbatas. Hal ini dikarenakan faktor waktu dan biaya yang tersedia. Populasi penelitian ini adalah para guru, kepala sekolah, dan para pengawas SD di seluruh Bali. Populasi dari penelitian ini dikatagorikan populasi terhingga yang ditelusuri pada menjelang penelitian dilakukan. Sampling yang dipilih adalah multistage sampling, yaitu penarikan sampel dilakukan secara bertahap (Dantes, 2013). Prosedur penarikan sampel ditempuh dengan cara sebagai berikut: (a) pertama, Provinsi Bali dibagi empat yang terdiri dari Bali Timur diwakili oleh Kabupaten Karangasem, Bali Selatan diwakili oleh Kabupaten Badung, Bali Barat diwakili oleh Kabupaten Jemberana; dan Bali Utara diwakili oleh Kabupaten Buleleng; (b) kedua, kemudian secara random sampling di setiap wilayah ditetapkan sejumlah 25 orang guru SD sebagai sampel penelitian, (c) ketiga, berdasarkan hasil random tahap kedua, ditetapkan semua guru kelas I,II,III SD dijadikan sampel. Data dikumpulkan dengan menggunakan teknik wawancara, kuesioner tertutup dan kuesioner yang terbuka. Analisis data dilakukan secara deskriptif kualitatif. Data yang sudah dikumpulkan dilakukan tabulasi data, kemudian menghitung nilai rata-rata membuat dan menetapkan kriteria kualitas secara kuantitatif, dan kemudian memberikan makna secara kualitatif. 


\section{HASIL DAN PEMBAHASAN}

1. Temuan penelitian yang pertama adalah bahwa hampir semua guru sekolah dasar (100 \%) di Bali menyatakan telah melakukan dan mentransformasikan nilai karakter sebanyak 20 nilai karakter dalam melaksanakan pembelajarannya di kelas. Kemudian nilai-nilai karakter tersebut meliputi (1) kesadaran moral, (2) pengetahuan nilai moral, (3) kemampuan memberi pandangan dan pertimbangan moral, (4) mengenal dan memahami diri, (5) pandangan terhadap pekerjaan, (6) kata hati/hati nurani, (7) harga diri, (8) empati, (9) cinta pada kebaikan, (10) pengendalian diri, (11) rendah hati, (12) rasa terharu, (13) kejujuran, (14) loyalitas, (15) keyakinan, (16) kompetensi moral, (17) kemauan, (18) kebiasan, (19) tanggungjawab, persahabatan keberanian, dan (20) keteguhan hati, ketekunan, dalam pengambilan keputusan.

Kualitas transformasi pendidikan tehnohumanistik guru-guru SD di Bali ditemukan cendrung dapat dikategorikan sangat baik, karena nilai rata-ratanya adalah sebesar 88,77 . Nilai angka 88,77 tersebut berada pada rentangan skor antara 80-100 (Sangat baik). Demikian pula ditemukan nilai rata-rata kualitas transformasi pendidikan nilai karakter atau tehnohumanistik guruguru SD di Bali barat 83,96, Bali selatan 85,64, dan Bali utara 87,2. Angka-angka tersebut menunjukan bahwa kualitas transformasi pendidikan tehnohumanistik guruguru SD di Bali barat, Bali selatan dan Bali utara cendrung dapat dikategorikan sangat baik karena berada pada rentangan skor antara 80-100 (Sangat baik). Kemudian nilai rata-rata kualitas transformasi pendidikan nilai karakter guru-guru SD di Bali timur adalah sebesar 66,28 . Angka tersebut menunjukan bahwa kualitas model transformasi pendidikan karakter atau tehnohumanistik guru-guru SD di Bali timur cendrung dapat dikategorikan cukup baik karena berada pada rentang skor antara 5267 (Cukup baik).

2. Temuan penelitian yang kedua adalah bahwa semua guru-guru SD sebanyak 100 orang guru (100\%) yang ditunjuk sebagai sampel dalam penelitian ini menyatakan telah melakukan pembelajaran tematik pada waktu mengajar di kelas. Disamping itu guru-guru juga menyatakan menerapkan modelmodel pembelajaran yang lainnya, yang kalau dilihat dari jumlah guru yang menerapkannnya dapat dirinci sebagai berikut: model pembelajaran CTL 33\%, ceramah 19\%, kerja kelompok dan penugasan masingmasing 17\%, jigsaw, tanya jawab masing-masing $16 \%$, diskusi $15 \%$, STAD $11 \%$, demontrasi dan pemecahan masalah masing-masing $8 \%$, inquiry $6 \%$, CBSA dan quantum masing-masing $3 \%$, SAS dan Eja masing-masing $2 \%$, dan pakem $1 \%$. Temuan ini juga didukung oleh temuan di Bali barat, selatan, timur dan di Bali utara.

3. Temuan yang ketiga bahwa guruguru sekolah dasar di Bali dalam pengembangan pembelajaran tematik di lapangan secara umum dalam setiap tahap atau langkah

Jurnal Pendidikan Indonesia/ 607 
kegiatan pembelajarannya, yaitu langkah kegiatan pertama, kedua, dan ketiga tampak terjadi perbedaan kegiatan dan bahkan mungkin oleh seorang guru tertentu tidak dilakukan, namun demikian secara teoritis langkah-langkah yang sudah dilakukan tersebut dapat dikatakan sudah baik. Namun demikian masih ada kelemahannya karena berbagai kegiatan yang seharusnya dilakukan dalam setiap langkah kegiatan tersebut cendrung tidak dilakukan. Secara jelas dan lebih rinci kelemahannya jelas dapat dilihat dari prosentase jumlah guru yang melakukannya. Dari semua guru yang ditunjuk menjadi sampel yang jumlahnya 100 orang, ternyata prosentase jumlah guru yang melakukannya pada suatu kegiatan tertentu lebih kecil dari 100 orang paling banyak pada suatu kegiatan tertentu sekitar $76 \%$. Temuan yang secara umum di Bali ini dapat diperjelas dan diperkuat kembali dengan temuan di Bali barat, selatan, timur dan dan di Bali utara.

Dari ketiga temuan di atas temuan pertama menunjukkan bahwa guru-guru sekolah dasar di Bali menunjukkan telah melaksanakan dan sudah mampu mengembangkan pembelajaran nilai karakter atau transformasi pendidikan tehnohumanistik yang terintegrasi dengan pembelajaran tematik. Sebanyak 20 nilai karakter dapat diintegrasikan dengan pembelajaran tematik dan dengan sangat baik. Temuan ini sejalan dan sesuai dengan penelitian hasil penelitian Dantes (2010) yang mengambil fokus pendidikan karakter berbasis teknohumanistik di sekolah formal di Indonesia.

Di sisi yang lain kalau ketiga temuan tersebut dicermati secara hatihati maka sesungguhnya masingmasing dari ketiga temuan tersebut menunjukkan bahwa dalam menerapkan transformasi pendidikan tehnohumanistik yang terintegrasi dengan pembelajaran tematik masih ada kelemahannya, seperti temuan nomor 1 secara jelas terungkap di Bali timur bahwa kualitas transformasi pendidikan tehnohumanistik masih cendrung cukup, dari sisi frekuensi penerapannya masih sekitar $7 \%$ masih kurang dan bahkan tidak pernah melakukannya. Dalam temuan yang kedua masih banyak guru-guru yang menggunakan model pembelajaran selain model tematik, lebih-lebih guruguru yang mengajar di kelas I, II, dan III yang seharusnya menggunakan pembelajaran tematik. Demikian juga dalam temuan yang ketiga secara jelas dalam melakukan kegiatan dalam setiap tahap atau langkah pembelajaran tematik masih sedikit guru yang melakukannya, bahkan dalam melakukan suatu kegiatan tertentu yang seharusnya dilakukan dalam langkah pertama atau pendahuluan dilakukan pada langkah kedua atau, bahkan dalam langkah ketiga atau dalam langkah penutupan pembelajaran.

Berbagai kekurangan ini terjadi karena sekitar $40 \%$ guru-guru SD di Bali yang ditunjuk sebagai sampel dalam penelitian ini statusnya adalah sebagai guru mengabdi, guru kontrak, guru honor. Demikian juga dari segi latar belakang pendidikannya yang terakhir berlatar belakang pendidikan D2, sarjana olahraga, sarjana agama. Dari 
sisi jumlah guru yang berstatus pegawai negeri sipil rata-rata jumlahnya terbatas bahkan beberapa sekolah masih kurang dan belum tersertifikasi. Guru-guru SD di lapangan sekitar $60 \%$ mengajar di kelas I, II, III, IV, V dan VI sebagai guru mata pelajaran. Rata-rata belum mendapat pelatihan dan kegiatan inservis yang sejenis lainnya, dan kurang bahkan tidak mendapat pembinaan akademik dari kepala sekolah dan dari pengawas secara memadai dan baik.

Frofil guru SD yang digambarkan tersebut jelas belum profesional, yang berdampak dan mengakibatkann pada kualitas pembelajaran guru-guru menjadi rendah, khususnya dalam menerapkan transformasi pendidikan teknohumanistik dan model pembelajaran tematik.

\section{PENUTUP}

1. Bahwa hampir semua guru sekolah dasar (100 \%) di Bali menyatakan sudah menerapkan transformasi pendidikan teknohumanistik, yang meliputi sebanyak 20 nilai karakter dalam melaksanakan pembelajaran di kelas. Kemudian nilai-nilai karakter tersebut meliputi (1) kesadaran moral, (2) pengetahuan nilai moral, (3) kemampuan memberi pandangan dan pertimbangan moral, (4) mengenal dan memahami diri, (5) pandangan terhadap pekerjaan, (6) kata hati/hati nurani, (7) harga diri, (8) empati, (9) cinta pada kebaikan, (10) pengendalian diri, (11) rendah hati, (12) rasa terharu, (13) kejujuran, (14) loyalitas, (15) keyakinan, (16) kompetensi moral, (17) kemauan, (18) kebiasan, (19) tanggungjawab,

persahabatan keberanian, dan (20) keteguhan hati, ketekunan, dalam pengambilan keputusan.

Kualitas transformasi pendidikan tehnohumanistik guru-guru SD di Bali skor rata-ratanya adalah sebesar 88,77. Angka tersebut menunjukan bahwa kualitas transformasi pendidikan tehnohumanistik guru-guru SD di Bali cendrung dapat dikategorikan sangat baik karena berada pada rentangan skor antara 80-100 (Sangat baik). Demikian pula ditemukan nilai rata-rata kualitas transformasi pendidikan nilai karakter atau tehnohumanistik guruguru SD di Bali barat 83,96, Bali selatan 85,64, dan Bali utara 87,2. Angka-angka tersebut menunjukan kualitas transformasi pendidikan nilai karakter atau tehnohumanistik guruguru SD di Bali barat, selatan dan utara cendrung dapat dikategorikan sangat baik karena berada pada rentangan skor antara 80-100 (Sangat baik). Kemudian nilai ratarata kualitas pendidikan transformasi nilai-nilai tehnohumanistik guru-guru SD di Bali timur adalah sebesar 66,28 . Angka tersebut menunjukan bahwa kualitas transformasi pendidikan tehnohumanistik guruguru SD di Bali timur cendrung dapat dikategorikan cukup baik karena berada pada rentang skor antara 5267 (Cukup baik).

2. Bahwa semua guru-guru SD sebanyak 100 orang guru (100\%) menyatakan telah melakukan pembelajaran tematik pada waktu mengajar di kelas. Disamping itu guru-guru juga menyatakan menerapkan model-model 
pembelajaran yang lainnya, yang kalau dilihat dari jumlah guru yang menerapkannnya dapat dirinci sebagai berikut: model pembelajaran CTL 33\%, ceramah 19\%, kerja kelompok dan penugasan masingmasing $17 \%$, jigsaw, tanya jawab masing-masing $16 \%$, diskusi $15 \%$, STAD $11 \%$, demontrasi dan pemecahan masalah masing-masing $8 \%$, inquiry $6 \%$, CBSA dan quantum masing-masing $3 \%$, SAS dan Eja masing-masing $2 \%$, dan pakem $1 \%$.

3. Temuan yang ketiga adalah secara umum bahwa dalam pengembangan dan melaksanakan transformasi pendidikan tehnohumanistik yang dintegrasikan dengan model pembelajaran tematik guru-guru SD di Bali dalam setiap langkah kegiatannya, dalam langkah kegiatan pertama, kedua, dan ketiga tampak terjadi perbedaan kegiatan dan bahkan mungkin kegiatan tertentu oleh beberapa orang guru tidak dilakukan, namun demikian secara teoritis langkah-langkah yang sudah dilakukan tersebut dapat dikatakan sudah baik. Namun demikian masih ada kelemahannya karena berbagai kegiatan yang seharusnya dilakukan dalam setiap langkah kegiatan cendrung tidak dilakukan. Secara jelas dan lebih rinci kelemahannya tersebut dapat dilihat dari prosentase jumlah guru yang melakukannya. Dari semua guru yang ditunjuk menjadi sampel yang jumlahnya 100 orang, ternyata prosentase jumlah guru yang melakukannya pada suatu kegiatan tertentu lebih kecil dari 100 orang hanya sekitar $76 \%$ yang paling banyak.

Berpijak pada hasil pembahasan terhadap temuan penelitian, maka dapat diajukan beberapa saran sebagai berikut di bawah ini.

1. Pemerintah kabupaten daerah tingkat II dan tingkat I Vropinsi Bali supaya didalam perekrutan guru sekolah dasar konsisten mengikuti peraturan yang berlaku, seperti memperhatikan rasio guru jumlah kelas dan jumlah murid, calon guru supaya lulusan program D4/S1 kependidikan. Guru honor, guru yang mengabdi, dan guru kontrak sebaiknya lulusan program D4/S1 kependidikan. Demikian juga Dinas Pendidikan sebagai bagian instansi dari pemerintah daerah supaya memberikan peluang dan memfasilitasi kepada guru-guru untuk mengembangkan dirinya melalui penelitian, penataran dan pelatihan, dan forum sejenis yang lainnya, bahkan memfasilitasi penyediaan bantuan beasiswa kepada guru-guru yang memiliki peminatan dan kemampuan untuk melanjutkan ke jenjang pendidikan yang lebih tinggi atau studi lanjut ke program S2.

2. Pengawas yang ada di setiap UPT supaya melaksanakan tupoksinya sebagai supervisor yang baik dalam rangka membantu dan membina guru-guru dalam bidang akdemiknya dengan memanfaatkan gugus sekolah,

sekolah inti, guru sejenis, kunjungan kelas, dan teknik supervisi yang lainnya.

Jurnal Pendidikan Indonesia/ 610 
3. Kepala sekolah supaya melaksanakan tupoksinya dengan baik khususnya sebagai supervisor dalam rangka membantu dan membina guru-guru dalam bidang akademiknya.

\section{DAFTAR PUSTAKA}

Dantes, N. (2008). Pengembangan model dan materi pendidikan multikultur dalam pembelajaran IPS dan PKn SMP (laporan penelitian). Singaraja: Lembaga Penelitian Undiksha.

Dantes, N. (2009). Pendidikan teknohumanistik (suatu rangkaian perspektif dan kebijakan pendidikan menghadapi tantangan global) (Makalah). Universitas Pendidikan Ganesha: Panitia Konaspi

Departemen Pendidikan Nasional Republik Indonesia (2003). Undang-undang Republik Indonesia Nomor 20 Tahun 2003 Tentang Sistem Pendidikan Nasional.

Departemen Pendidikan Nasional Republik Indonesia (2005). Peraturan Pemerintah Republik
Indonesia Nomor 19 tahun 2005 Tentang Standar Nasional Pendidikan.

Elmubarok, E. (2009). Membumikan pendidikan nilai, mengumpulkan yang terserak, menyambung yang terputus dan dan menyatukan yang tercerai. Bandung: Alfabeta.

Lickona, T. (1996). Eleven principles of effective character education. Journal of Moral Education. 1, 1996, pp.93-94.

McRae H. (1995). Dunia di tahun 2020 kekeuasaan, budaya, dan kemakmuran wawasan tentang masa depan. Jakarta: Binarupa Aksara.

Naisbitt J. (1995). Megatrends Asia. Jakarta: Binarupa Aksara.

Naisbitt J. \& Patricia Aburdene. (1995) sepuluh arah baru untuk tahun1990-an megatrends 2000. Jakarta. Binarupa Aksara.

Rohman, M. (2012). Kurikulum berkarakter, refleksi dan proposal solusi terhadap KBK dan KTSP. Jakarta: Prestasi Pustaka.

Suriasumantri, J. S. (1984). IImu dalam persepektif. Jakarta: PT Gramedia. 